\title{
Spatial patterns of two co-occurring savanna and forest tree species in a dense fire-protected savanna fragment
}

\author{
Rafael Carvalho da Costa ${ }^{13^{*}}$ and Flavio Antonio Maës dos Santos ${ }^{2}$
}

Received: April 22, 2016

Accepted: October 6, 2016

\begin{abstract}
Savanna-forest transition under fire-exclusion could be explained by differential competitive performance of savanna and forest species under shading/fire-exclusion. Aiming to understand strategies related to either habitat affinity, we investigated spatial patterns of a savanna and a forest species in a fire-protected savanna. We predicted that: savanna species would have lower abundance than the forest species due to a restriction in the number of open microsites; segregation of size classes and a trend from clumping to regularity with size for forest species due to absence of microsite limitation and intra-specifc competition; and spatial association and increasing clustering with size for savanna species due to microsite limitation. To test these predictions, we described spatial patterns of plants in two size classes in three plots of 0.5 ha. We analyzed spatial patterns and associations of size classes using SADIE methodology. Different from what we expected, both species were more abundant among the studied plots and exhibited an increasing aggregation from small to large size classes. We also found a positive spatial association between size classes of both. These results suggest that both savanna and forest species produce similar spatial patterns independently of habitat affinity. We discuss the possible processes responsible for the observed patterns.
\end{abstract}

Keywords: Cerrado, competition, fire, microsite limitation, recruitment, SADIE, savanna, spatial patterns

\section{Introduction}

Plant responses to physical and biotic environments can vary depending on developmental stage (Harper \& White 1974). Such developmental variation can be related to shifts in suitable sites for survival and growth throughout ontogeny, and thereby influencing spatial and size/age population structure, especially in heterogeneous environments (Schupp 1995). Details of spatial patterns throughout ontogeny can be suggestive of factors influencing demographic processes (Barot et al. 1999; Barot \& Gignoux 2003; Schurr et al. 2004; Raventós et al. 2010). Therefore, the assessment of variation in spatial patterns throughout ontogeny is one way to verify how different demographic processes influence populations of plant species.

Different suites of processes are associated with either discordance (trend of occurrence in distinct locations) or concordance (trend to occur in close proximity) of spatial patterns of developmental stages/size classes. Discordance can be a result of microsite differences throughout ontogeny (Schupp 1995; Anderson et al. 2009), intraspecific competition (Stoll \& Prati 2001; Raventós et al. 2010) and negative density dependence (Janzen 1970; Gratzer \& Rai 2004); whereas concordance can be a consequence of facilitative (intra- or inter-specific) interactions (Callaway 1995; Gratzer \& Rai 2004) or similarities in suitable

\footnotetext{
${ }^{1}$ Departamento de Biologia, Centro de Ciências, Universidade Federal do Ceará. Av. Humberto Monte, 60440-554, Fortaleza, CE, Brazil

${ }^{2}$ Departamento de Biologia Vegetal, Instituto de Biologia, Universidade Estadual de Campinas, 13083-970, Campinas, SP, Brazil

${ }^{3}$ Programa de Pós Graduação em Biologia Vegetal, Universidade Estadual de Campinas, 13083-970, Campinas, SP, Brazil

* Corresponding author: carvalhorafael@yahoo.com
} 
microsites between stages/classes (Barot \& Gignoux 2003; Gratzer \& Rai 2004). Detecting discordance or concordance can help reject hypotheses of which processes influence demography of plant populations. Further details of spatial patterns, such as general type, intensity and scales (Legendre \& Fortin 1989; Dale 1999), allow choices to be made among alternative hypotheses about demographic processes (Liebhold \& Gurevitch 2002). For example, under spatial discordance among stages it is possible to regard either microsite differences or intraspecific competition as generating processes, but under density dependence a trend toward regularity in later stages of development is expected, whereas under the microsite hypothesis all stages are expected to be aggregated in their preferred microsites. Therefore, a full description of the spatial structure and associations of developmental stages is necessary to disentangle patterns suggestive of different demographic processes.

Savanna and forest physiognomies can change from one to the other in a quite abrupt way, often exhibiting dissimilarities in tree species composition (Felfili \& Silva Júnior 1992; Hopkins 1992; Durigan \& Ratter 2006; Geiger et al. 2011), or they can constitute smooth transitions, forming ecotones where species of both physiognomies coexist (Durigan et al. 2003). Which processes are responsible for these shifts have been the focus of a discussion on the stability of savanna and forest physiognomies (Jeltsch et al. 2000; Staver et al. 2011). One of the explanations is that fire is a factor that prevents the establishment of fire-sensitive forest species in savannas and that savanna species do not establish into forest sites because they are poor competitors in low light conditions (Hoffmann 1998; Hoffmann \& Franco 2003; Hennenberg et al. 2005; Geiger et al. 2011). According to this hypothesis, when forest and savanna species co-occur, differences in processes that shape the demography of each type of species are expected because they should respond differentially to the same environment. Intermediate situations where fire is nearly absent and where there is some light limitation are suitable for testing this idea because both kinds of species are able to coexist. In this study we aimed to investigate differences in the processes that shape the demography of savanna and forest species co-occurring in the same fragment by a comparative study of spatial patterns of tree species of the Brazilian Cerrado. Cerrado is a tropical complex of three biomes: grasslands, savannas and seasonal forests (Batalha 2011), and transitions from forest to grassland and savanna are frequently abrupt (Felfili \& Silva Júnior 1992; Ratter 1992; Durigan \& Ratter 2006; Geiger et al. 2011). To understand the ecological differences related to either forest or savanna affinity, we chose to study species associated with each of them in a fire protected Cerrado fragment where the light environment is heterogeneous, with predominance of shade conditions (Miranda-Melo 2004 and see "Study area" in "Materials and methods" for further details). Under these conditions, we hypothesize that different processes influence the demography of each species due to their different habitat affinities. We predicted that: 1) the savanna species will have lower abundance than the forest species due to a restriction in the number of open microsites for survival, and that fire sensitive forest species should have higher abundance due to fireprevention; 2) because forest species are adapted to more shaded environments, they should not be microsite limited, and exhibit spatial discordance among size classes and a trend from clumping to regularity with size due to strong intra-specific competition; 3) savanna species should be microsite limited and exhibit positive spatial association and increasing clustering with size. Specifically, we aimed to answer the following questions: Does the relative abundances of the two species differ? What are the spatial patterns of size classes in different locations within the same fragment for each species? Is there intra-specific associations (positive or negative) among different size classes?

\section{Materials and methods}

\section{Study area}

We collected data at the Itirapina Experimental Station (IES), in the state of São Paulo, Brazil ( $22^{\circ} 15^{\prime} \mathrm{S}$ and $47^{\circ} 48^{\prime} \mathrm{W}$; elevations near $760 \mathrm{~m}$ a.s.l.). The climate is altitude tropical corresponding to Köppen's Cwa with dry winters and wet warm summers. The average annual precipitation and temperature are $1450 \mathrm{~mm}$ and $21^{\circ} \mathrm{C}$, respectively (CEPAGRI/ UNICAMP 2006). In IES, there are several physiognomies of Cerrado, but there is a predominance of woodlands of different levels of openness. Cerrado vegetation occurs in IES as fragments in a matrix of Pinus sp. For this study we choose a 139.1 ha fragment on Arenosols, with three permanent plots already established for population structure studies (Miranda-Melo et al. 2007). The plots were placed in locations with similar physiognomies: a dense Cerrado woodland, where the tree layer is nearly eight meters in height, resulting in a heterogeneous light environment (Miranda-Melo et al. 2007), a near absence of grass and the presence of litter. There is some light limitation, as evidenced by the absence of a continuous layer of grass and a percentage of canopy openness (measured by analysis of fish-eye lens photographs taken $1.3 \mathrm{~m}$ from ground level) commonly around $20 \%$, but rarely passing $30 \%$ (MirandaMelo 2004). The species with the highest value of importance in the fragment are Vochysia tucanorum (Spreng.) Mart, Myrcia linga O. Berg, Ocotea pulchella (Nees) Mez, Dalbergia miscolobium Benth and Qualea grandiflora Mart. (Aoki et al. 2006). Dalbergia miscolobium, a characteristic species of the cerradão (semideciduous forest, Ribeiro \& Walter 1998) has been increasing in importance value (Aoki et al. 2006), 
probably a consequence of fire protection permitting the invasion of forest species from nearby cerradão fragments (the nearest is located at a distance of $4.0 \mathrm{~km}$ from the study fragment). The fragment has been protected from fire and human disturbances for nearly 40 years, and is beginning to be invaded by Pinus sp.

\section{Study species}

To understand ecological differences related to either forest or savanna affinity we choose to study one species associated with each physiognomy. The studied species were Qualea grandiflora and Vochysia tucanorum (Vochysiaceae). Information from the literature has shown habitat differences between them, with $V$. tucanorum being mainly found in forests or forest-savanna transitions (Gandolfi et al. 1995; Barbosa et al. 1999; Geiger et al. 2011). Gandolfi et al. (1995) included $V$. tucanorum in the group of early secondary species, tolerating intermediate levels of shading. Q. grandiflora, on the other hand, has been recorded as a typical savanna species (Felfili \& Silva Júnior 1992; Geiger et al. 2011). Experimental studies show that light enhances this species germination (Felippe 1990), and under soil nutrient enrichment seedlings of $Q$. grandiflora invest more into underground than aboveground structures (Paulilo \& Felippe 1995), suggesting that Q. grandiflora has better performance in more "open" conditions where light is not limiting. Although the above studies support differences in habitat preferences, Q. grandiflora and V. tucanorum can be found at the same localities (Costa \& Araújo 2001; Weiser \& Godoy 2001; Silva et al. 2002; Gomes et al. 2004), which makes them suitable for this comparative study.

\section{Data collection}

We collected data in three $100 \times 50 \mathrm{~m}$ permanent plots (hereafter referred as V1, V2, V3) installed in different locations within our fragment. Each plot was divided into $2005 \times 5$ m subplots. In each subplot we counted and measured the height of individuals of $Q$. grandiflora and $V$. tucanorum. Height measurements were done using a metric tape for plants up to nearly two meters tall and a clinometer for taller plants (Precision $0.01 \mathrm{~m}$ ).

\section{Data analysis}

For all analyses we considered two size classes: plants with $0.15 \mathrm{~m} \leq$ height $\leq 1.5 \mathrm{~m}$, and plants with height $>1.5$ $\mathrm{m}$. The maximum attained height registered in studied plots was $14.08 \mathrm{~m}$ for Q. grandiflora and $13.53 \mathrm{~m}$ for $V$. tucanorum. The choice of the number and range of classes was a compromise between a sufficient number of plants within each class for spatial analysis $(\sim 20)$, with the similarity of classes being compared in all plots and species combinations, and an approximation to the distinction between mature and immature trees.

To test for differences in abundance between species in different plots within the same fragment (V1, V2, V3), we performed chi-square tests for the tall size class.

We used the number of plants per subplot as a variable describing the spatial patterns of populations of $Q$. grandiflora and V. tucanorum. To measure and test for the presence of spatial structure we performed Spatial Analysis by Distance Indices (SADIE) (Perry 1998). This analysis allows a description of spatial patterns of count data by means of computation of an index of aggregation, Ia. Values of Ia not significantly different from 1 indicate spatially random data, whereas Ia $>1$ and Ia $<1$ means aggregated and regular spatial patterns, respectively. The significance of Ia was tested by means of a randomization procedure (Perry 1998). At each run, the subplot position of counts were changed randomly permitting one to build a random distribution of Ia values thereby making it possible to assign a p-value for empirically obtained values and to test for its significance on an established level (5\% in this study; 5967 permutations, the maximum possible in the software used).

We tested intra-specific spatial associations between size classes of each species by SADIE methodology for spatial associations (Perry \& Dixon 2002). The procedure consisted of computing local clustering indexes for each sample unit (subplots). Clustering indexes were than used for computing an $\mathrm{X}$ value for two sets of count data obtained in the same sample units. $\mathrm{X}$ values are simple correlation coefficients between the correspondent clustering indexes (obtained for each sample unit in the previous analysis) of each set of counts. The significance of $\mathrm{X}$ values were computed under the null hypothesis of absence of association or dissociation and tested by means of a randomization test. The randomization involved the computation of the clustering indexes obtained from permutation of observed counts amongst the sample units (subplots) in both count data sets (more details on significance tests in Perry \& Dixon 2002). We performed 10000 randomizations. A significant positive value of $X$ indicates spatial association and a negative value indicates spatial dissociation. All spatial analysis were performed in SADIEShell (measuring and testing spatial structures) and N_Ashell (spatial association) software (Conrad 2008).

\section{Results}

The abundance of the tall size class differed between species in different places of the same fragment (chisquare $=114.6, \mathrm{df}=2, \mathrm{p}<0.01$ ), but neither species was the most abundant in all studied plots (Tab. 1). This seems mainly due to differences in abundances of species in V2 (Q. gandiflora more abundant than V. tucanorum) and V3 (V. tucanorum more abundant than $Q$. gandiflora) because the largest deviations from expected values computed for the chi-square tests were found in these plots. 
For V. tucanorum, we found a predominance of aggregated spatial patterns with only one case of randomness (Tab. 2, Fig. 1). There was an increase in aggregation from small to tall height classes of V. tucanorum. In V1 there was a transition from randomness to clumped spatial pattern and in V2 and in V3 both size classes were clumped, with a high level of aggregation in tall size class (Tab. 2). Small and tall size classes of $V$. tucanorum were spatially associated in V2 and V3, and nearly significantly associated in V1 (Tab. 3).

For Q. grandiflora, we found a similar trend of increasing aggregation from small to tall size classes in all three plots (Tab. 2, Fig 2.). In V2 and V3 the trend was represented by a transition from random spatial distribution in the small size class to aggregated patterns in the tall size class, and in V1 the trend consisted of an increase in aggregation from small to tall size class (Tab. 2). In V2 both size classes of $Q$. grandiflora were spatially associated but they had no significant association or dissociation in V1 and V3 (Tab. 3).

\section{Discussion}

The studied species exhibited similar spatial patterns of increasing aggregation with increasing size class and a positive spatial association between size classes. These results were unexpected because we had hypothesized that because the studied species have different habitat affinities (savanna $\mathrm{x}$ forest), they should exhibit different spatial patterns suggestive of contrasting demographic responses to the same environment.

For Q. grandiflora, clumping only in tall size class in V2 and V3, an increased aggregation with size class in V1 and one case of inter-class spatial association suggest a scenario where, despite low early specificity, recruitment into maturity is only possible in some suitable locations. Clumped spatial patterns of mature size classes or stages have been documented and related to soil and topographic factors (Tsujino \& Yumoto 2007; Anderson et al. 2009; Franklin \& Santos 2011; Barbosa et al. 2013), and light (Dovciak et al. 2001; Fuchs et al. 2013).

We regard light as a more limiting factor to $Q$. grandiflora recruitment into maturity in the studied fragment than soil. First, because Q. grandiflora, being the most widespread tree species of the Cerrado (Ratter et al. 2003), should have high tolerance to soils with low fertility or Al toxicity, both characteristics of Cerrado soils (Motta et al. 2002). Second, because in the studied fragment plants have a high probability of experiencing light limitation as they grow due to the canopy openness ranging from low to moderate, rarely passing $30 \%$, with common values around 20\% (Miranda-Melo 2004). This becomes more evident considering that Miranda-Melo et al. (2007) found a mean canopy openness (computed from fisheye photographs) of 19.6, 29.4 and $28.6 \%$ in the same plots we studied here (V1, V2, V3, respectively), with V1 being the plot were light is more limiting. We found that for $Q$. grandiflora both the
Table 1. Number of individuals of tree species in two size classes in three $100 \times 50 \mathrm{~m}$ plots (V1, V2, V3) in a Cerrado (wet savanna) fragment, São Paulo, Brazil. QG - Qualea grandiflora, VT - Vochysia tucanorum.

\begin{tabular}{|c|c|c|c|c|c|c|}
\hline Plot & \multicolumn{2}{|c|}{ Height $\leq 1.5 m$} & \multicolumn{2}{|c|}{ Height $>1.5 m$} & \multicolumn{2}{|c|}{ Total } \\
\hline & QG & VT & QG & VT & QG & VT \\
\hline V1 & 31 & 47 & 230 & 229 & 261 & 276 \\
\hline V2 & 41 & 22 & 122 & 34 & 163 & 56 \\
\hline V3 & 19 & 83 & 32 & 137 & 51 & 220 \\
\hline
\end{tabular}

Table 2. Spatial patterns of the number individuals of Qualea grandiflora (QG) and Vochysia tucanorum (VT) in two size classes (S-small, T-tall) in three $100 \times 50$ plots (V1, V2, V3) in a cerrado (wet savanna) fragment, São Paulo, Brazil. Ia - SADIE index of aggregation, $\mathrm{p}$ - significance of each Ia. Significance values smaller than the critical values $(0.05)$ are in boldface.

\begin{tabular}{|c|c|c|c|c|}
\hline Plot & Species & Class & la & $\mathbf{p}$ \\
\hline v1 & QG & T & 2.226 & $\mathbf{0 . 0 0 0 2}$ \\
\hline v1 & QG & S & 1.715 & $\mathbf{0 . 0 0 5 9}$ \\
\hline v2 & QG & T & 1.789 & $\mathbf{0 . 0 0 2 3}$ \\
\hline v2 & QG & S & 1.228 & 0.1156 \\
\hline v3 & QG & T & 1.858 & $\mathbf{0 . 0 0 2 2}$ \\
\hline v3 & QG & S & 1.189 & 0.1483 \\
\hline v1 & VT & T & 2.224 & $\mathbf{0 . 0 0 0 2}$ \\
\hline v1 & VT & S & 1.342 & 0.615 \\
\hline v2 & VT & T & 2.208 & $\mathbf{0 . 0 0 0 3}$ \\
\hline v2 & VT & S & 1.791 & $\mathbf{0 . 0 0 3 2}$ \\
\hline v3 & VT & T & 2.302 & $\mathbf{0 . 0 0 0 2}$ \\
\hline v3 & VT & S & 1.872 & $\mathbf{0 . 0 0 1 8}$ \\
\hline & & & & \\
\hline
\end{tabular}

Table 3. Spatial association of the number of individuals between small and tall size classes of Qualea grandiflora (QG) and Vochysia tucanorum (VT) in three $100 \times 50$ plots (V1, V2, V3) in a Cerrado (wet savanna) fragment, São Paulo, Brazil. X - SADIE index of association, $\mathrm{p}$ - significance of each $\mathrm{X}$. Significance values smaller than the critical values (0.05) are in boldface.

\begin{tabular}{|c|c|c|c|}
\hline Plot & Species & $\mathbf{X}$ & $\mathbf{p}$ \\
\hline v1 & QG & -0.0336 & 0.664 \\
\hline v2 & QG & 0.2775 & $\mathbf{0 . 0 0 1 2}$ \\
\hline v3 & QG & 0.0065 & 0.4757 \\
\hline v1 & VT & 0.1315 & 0.0527 \\
\hline v2 & VT & 0.2986 & $\mathbf{0 . 0 0 0 1}$ \\
\hline v3 & VT & 0.3930 & $\mathbf{0 . 0 0 0 1}$ \\
\hline
\end{tabular}

highest index of aggregation (Ia) of tall size class and the only significant positive association between small and tall size classes occurred in V1. The results of MirandaMelo et al. (2007) and ours suggest that individuals of Q. grandiflora tend to be more aggregated were light is more limiting. Preceding studies have also found results suggesting that Q. grandiflora has better performance in 

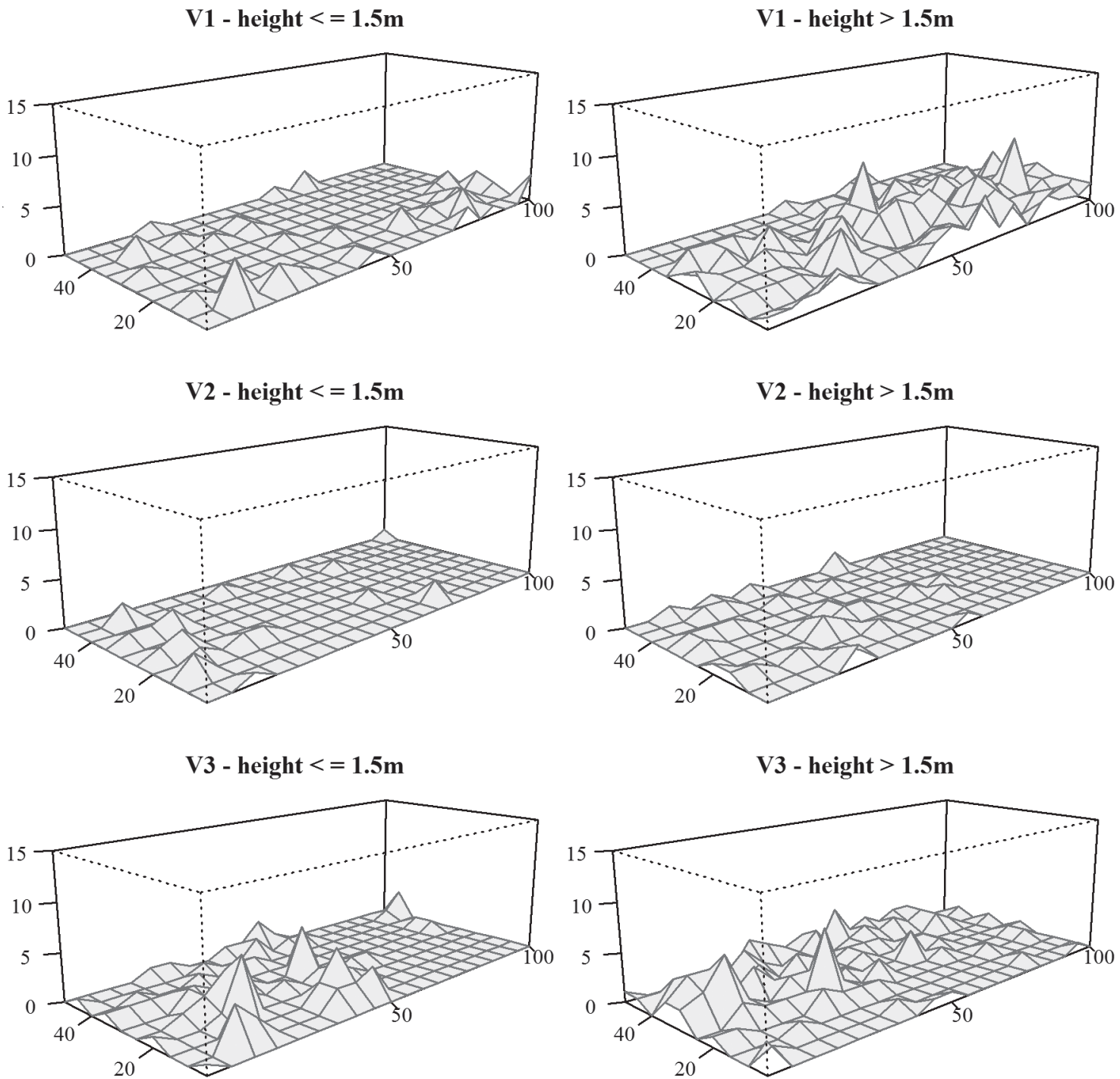

Figure 1. Perspective plots of the number of Vochysia tucanorum trees per $5 \times 5 \mathrm{~m}$ subplots (vertical axis) in $100 \times 50 \mathrm{~m}$ plots located in a Cerrado fragment, Itirapina, São Paulo. Plots for small and large size classes are on the left and right columns, respectively.

more "open" conditions where light is not limiting (Felippe 1990; Paulilo \& Felippe 1995). Taken together, these results are evidence that $Q$. grandiflora has better performance in more "open" conditions where light is not limiting, hence its recruitment into maturity should be restricted to less shaded microsites in savanna-to-forest transitions generating the observed spatial patterns.

The spatial patterns of $Q$. grandiflora could also be explained by a fire effect. In savannas, tree clumping can be generated by the influence of fire, either by enhanced survival due to crowd protection against fire damage or by fire induced re-sprouting in species with the ability to spread clonally (Kennedy \& Potgieter 2003). The studied fragment has been fire protected for 30-40 years and fire could explain tree clumping in this case only as a "memory" of spatial patterns left by a past of more frequent fire events.
If this is true, in fire protected fragments an expansion of establishment further from parent plants since fire exclusion is expected because recruitment would be "free" from the aggregative effects of fire. In this case, when comparing fire protected and unprotected fragments, spatial aggregation should be lower in intensity and larger in scale of aggregation (size of clumps) in fire protected fragments. In a study of spatial patterns of $Q$. grandiflora in fire-protected and unprotected Cerrado fragments, Costa \& Santos (2011) found results contrary to this expectation: in fire-prone fragments the intensity was equal to or lower than, and the scale of aggregation was similar to, that found in fireprotected fragments.

Spatial patterns of $V$. tucanorum were similar to that found for Q. grandiflora. This is an unexpected result because we expected forest species would not be microsite limited 

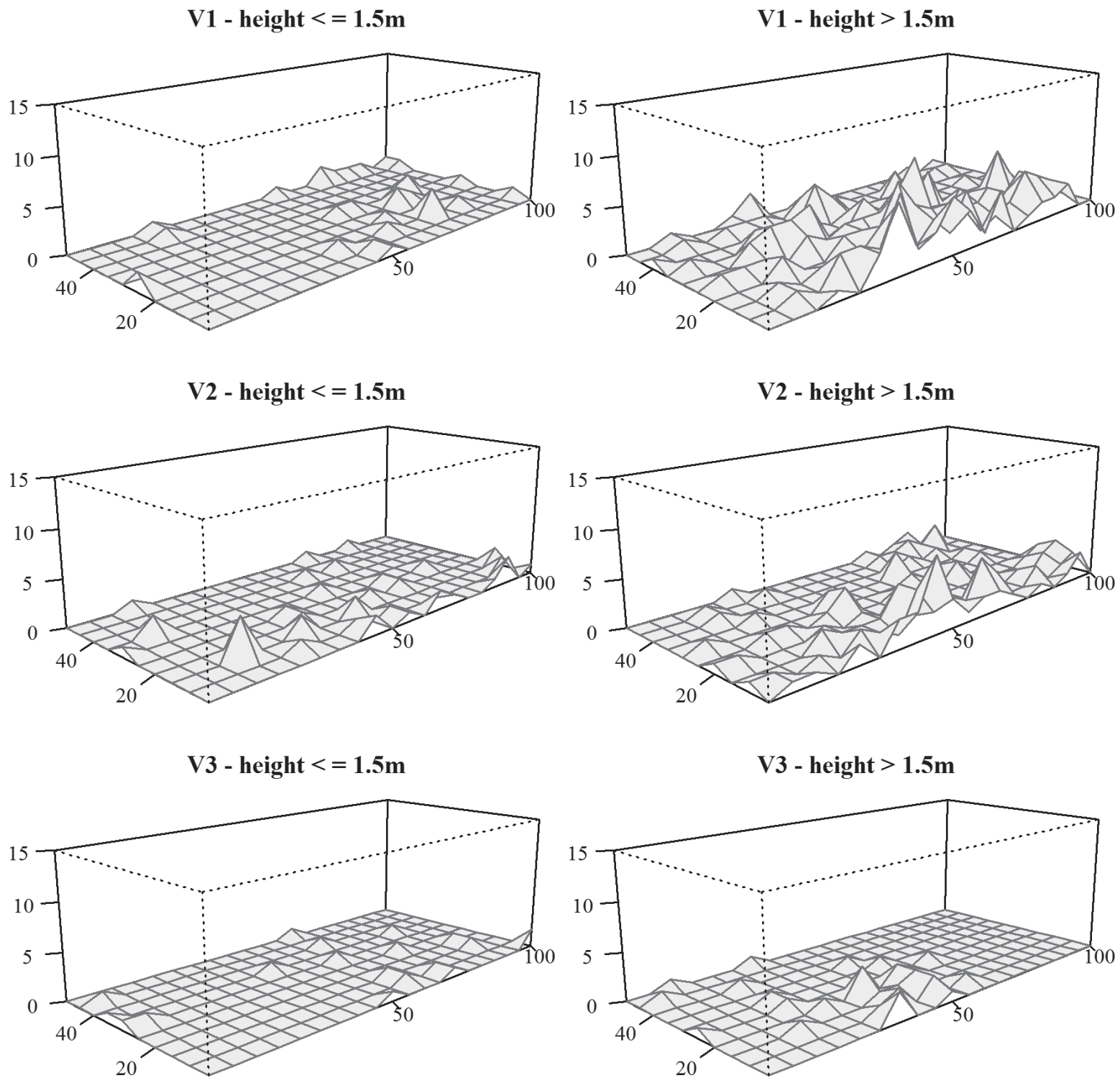

Figure 2. Perspective plots of the number of Qualea grandiflora trees per 5 x $5 \mathrm{~m}$ subplots (vertical axis) in $100 \times 50 \mathrm{~m}$ plots located in a Cerrado fragment, Itirapina, São Paulo. Plots for small and large size classes are on the left and right columns, respectively.

in more shaded conditions of fire-protected dense Cerrado vegetation. Experimental evidence shows that, although $V$. tucanorum germination is favored by light at some temperatures, its seeds are able to germinate both under light or dark conditions (Barbosa et al. 1999), showing that light is not important for germination. Additionally, even with the variation in mean canopy openness (19.6 - 28.6 $\%)$ among the studied plots (Miranda-Melo et al. 2007), the index of aggregation (Ia) for tall size class of $V$. tucanorum had very similar values among plots $(2.224,2.208,2.302)$ and spatial association was positively significant in two of them, suggesting that individuals of $V$. tucanorum do not tend to be more aggregated where light is more limiting, as for $Q$. grandiflora. Microsite limitation could be the process responsible for the spatial patterns of $V$. tucanorum due to a limited ability of forest species to reach deep water-reserves. Hoffmann \& Franco (2003), in a comparative growth analysis of pairs of congener woody species of savanna and forest found that while Cerrado species allocated more biomass to coarse roots, forest species allocated more to stem growth. Cerrado exhibits floristic/physiognomic gradients due to variation in soil fertility (mainly P, $\mathrm{N}$ and K; Goodland \& Pollard 1973) and fluctuations in water table level (Oliveira-Filho et al. 1989; Oliveira et al. 2005). Therefore, species with a limited ability to reach deep soil layers should be spatially associated with patches of soil with better fertility or a shallower water table. We failed to find any literature information on relative biomass investment in roots and aerial parts for V. tucanorum and, therefore, spatial dependence on patches of fertility or shallow water 
table by this species deserves further investigation.

An alternative for the microsite hypothesis could be that the spatial patterns of $V$. tucanorum are the result of spatial expansion of its population since initial colonization following fire-protection. Although not being microsite limited, the establishment of forest species into savannas could generate increasing aggregation with ontogeny and positive association of size classes because it should start with a low number of seeds that successfully establish and becomes mature trees acting as nuclei for further spreading of the invasion. For example, in a forest-savanna boundary in a Cerrado region near Brasilia, Brazil, 35 years of fireprotection (similar to our study) allowed the establishment of forest tree species that, although comprising a minority of the mature stems in savanna plots, corresponded to one-third of the juveniles (Geiger et al. 2011). Some of these juveniles were likely produced by early colonizers that probably acted as nuclei of invasion spreading. Some of our results give evidence for the importance of this process on $V$. tucanorum dynamics. When comparing maps of $V$. tucanorum, subplots of high density of small individuals surrounding plots of high density of larger individuals can be seen (in V1 and V2), suggesting expansion of establishment from an initial nucleus. Furthermore, we found evidence of a stronger positive spatial association among size classes for $V$. tucanorum than for Q. grandiflora. This consistent positive association could be the result of the importance of a few starting nuclei as a source of seeds for establishment of new cohorts and spatial expansion of populations.

The fact that both species were able to be more abundant relative to each other in different places (plots) of the same fragment is further evidence that $Q$. grandiflora should have its abundance restricted by the limitation of suitable places for survival until maturity. This species should be rare in locations with low availability of light microsites. Limitation of microsites defined by soil fertility or water table level remains a possible generating mechanism for the observed $V$. tucanorum spatial patterns, but we also find evidence that population expansion following fire-suppression could generate the observed patterns. Taken together, our results suggest that even having different affinities (forest x savanna), both species exhibited similar spatial patterns. To what extent this similarity can be the result of the same process (microsite limitation) deserves future study associating light and soil variables to survival of plants in different developmental stages of forest and savanna species and documenting spatial patterns, recruitment and survival of forest species invading savanna sites following fire-protection.

\section{Acknowledgements}

This work was supported by grants from Fundação de Apoio ao Ensino, Pesquisa e Extensão da UNICAMP (FAEPEX, 345/05) and Conselho Nacional de Desenvolvimento
Científico e Tecnológico (CNPq) to R.C.C. (130361/2005-4) and F.A.M.S. (304937/2007-0). We thank Instituto Florestal do Estado de São Paulo for authorization for field work (COTEC/IF 44.236/2004); K. Yamamoto, T.C.S. Spósito and reviewers for suggestions on this manuscript; Martins, V.F. for data analysis suggestions; and M.F. Filizola, C.B. Virilo, G.L.M. Barbosa and A.V. Christianini for help in field.

\section{References}

Anderson JT, Landi AA, Marks PL. 2009. Limited flooding tolerance of juveniles restricts the distribution of adults in an understory shrub (Itea virginica; Iteaceae). American Journal of Botany 96: 1603-11.

Aoki C, Pereira SR, Matos WH. 2006. Florística e fitossociologia de um fragmento de cerrado em Itirapina-SP. In: Santos FAM, Martins FR, Tamashiro JY. (orgs.) Relatórios de projetos desenvolvidos na disciplina NE211 - Ecologia de Campo II do Programa de Pós-Graduação em Ecologia, IB, UNICAMP. http://www.ib.unicamp.br/profs/fsantos/ ecocampo/ne211/2006/. 05 Oct. 2016.

Barbosa AR, Yamamoto K, Valio IFM. 1999. Effect of light and temperature on germination and early growth of Vochysia tucanorum Mart., Vochysiaceae, in cerrado and forest soil under different radiation levels. Revista Brasileira de Botânica 22: 275-280.

Barbosa CEA, Misiewicz TM, Fine PVA, Costa FRC. 2013. Plant ontogeny, spatial distance, and soil type influence patterns of relatedness in a common Amazonian tree. PLoS One 8:e62639. doi: 10.1371/journal. pone.0062639.

Barot S, Gignoux J. 2003. Neighbourhood analysis in the savanna palm Borassus aethiopum: interplay of intraspecific competition and soil patchiness. Journal of Vegetation Science 14: 79-88.

Barot S, Gignoux J, Menaut J. 1999. Demography of a savanna palm tree: predictions from comprehensive spatial pattern analyses. Ecology 80: 1987-2005.

Batalha M. 2011. O cerrado não é um bioma. Biota Neotropica 11: 0-4.

Callaway RM. 1995. Positive interactions among plants. Botanical Review 61: 306-349.

CEPAGRI/UNICAMP - Centro de Pesquisas Meteorológicas e Climáticas Aplicadas à Agricultura. 2006. Clima dos Municípios Paulistas (série histórica de 1961-1990). http://orion.cpa.unicamp.br/portal/modules. php?name=climasp\&file=municipios. 26 Jul. 2006.

Conrad KF. 2008. SADIE Reheated. http://home.cogeco.ca/ sadiespatial/ index.html. 15 May 2015.

Costa A, Araújo G. 2001. Comparação da vegetação arbórea de cerradão e de cerrado na Reserva do Panga, Uberlândia, Minas Gerais. Acta Botanica Brasilica 15: 63-72.

Costa RC, Santos FAM, 2011. Padrões espaciais de Qualea grandiflora Mart. em fragmentos de cerrado no estado de São Paulo. Acta Botanica Brasilica 25: 215-222.

Dale MRT. 1999. Spatial pattern analysis in plant ecology. Cambridge, Cambridge University Press.

Dovciak M, Frelich LE, Reich PB. 2001. Discordance in spatial patterns of white pine (Pinus strobus) size-classes in a patchy near-boreal forest. Journal of Ecology 89: 280-291.

Durigan G, Ratter JA. 2006. Successional changes in Cerrado and Cerrado/ Forest Ecotonal Vegetation in western São Paulo State, Brazil, 19622000. Edinburgh Journal of Botany 63: 119-130.

Durigan G, Siqueira MF, Franco GAD, Bridgewater S, Ratter JA. 2003. The vegetation of priority areas for Cerrado conservation in São Paulo State, Brazil. Edinburgh Journal of Botany 60: 217-241.

Felfili JM, Silva Júnior MC. 1992. Floristic composition, phytosociology and comparison of cerrado and gallery forests at Fazenda Água Limpa, Federal District, Brazil. In: Furley PA, Proctor JA, Ratter JA. (eds.) Nature and dynamics of forest-savanna boudaries. London, Chapman \& Hall. p. 393-415.

Felippe G. 1990. Qualea grandiflora: the seed and its germination. Revista Brasileira de Botânica 37: 33-37. 
Franklin J, Santos E V. 2011. A spatially explicit census reveals population structure and recruitment patterns for a narrowly endemic pine, Pinus torreyana. Plant Ecology 212: 293-306.

Fuchs E, Robles T, Hamrick J. 2013. Spatial distribution of Guaiacum sanctum (Zygophyllaceae) seedlings and saplings relative to canopy cover in Palo Verde National Park, Costa Rica. Revista de Biologia Tropical 61: 1521-1533.

Gandolfi S, Leitão Filho HF, Bezerra C L F. 1995. Levantamento florístico e caráter sucessional das espécies arbustivo-arbóreas de uma floresta mesófila semidecídua no município de Guarulhos, SP. Revista Brasileira de Biologia 55: 753-767.

Geiger EL, Gotsch SG, Damasco G, et al. 2011. Distinct roles of savanna and forest tree species in regeneration under fire suppression in a Brazilian savanna. Journal of Vegetation Science 22: 312-321.

Gomes B, Martins F, Tamashiro J. 2004. Estrutura do cerradão e da transição entre cerradão e floresta paludícola num fragmento da International Paper do Brasil Ltda., em Brotas, SP. Revista Brasileira de Botânica 27: 249-262.

Goodland R, Pollard R. 1973. The Brazilian cerrado vegetation: a fertility gradient. Journal of Ecology 61: 219-224.

Gratzer G, Rai PB. 2004. Density-dependent mortality versus spatial segregation in early life stages of Abies densa and Rhododendron hodgsonii in Central Bhutan. Forest Ecology Management 192:143-159.

Harper J, White J. 1974. The demography of plants. Annual Review of Ecology and Systematics 5: 419-463.

Hennenberg KJ, Goetze D, Minden V, et al. 2005. Size-class distribution of Anogeissus leiocarpus (Combretaceae) along forest-savanna ecotones in northern Ivory Coast. Journal of Tropical Ecology 21: 273-281.

Hoffmann W. 1998. Post-burn reproduction of woody plants in a neotropical savanna: the relative importance of sexual and vegetative reproduction. Journal of Applied Ecology 35: 422-433.

Hoffmann WA, Franco AC. 2003. Comparative growth analysis of tropical forest and savanna woody plants using phylogenetically-independent contrasts. Journal of Ecology 91: 475-484.

Hopkins B. 1992. Ecological processes at the forest-savanna boundary. In: Furley PA, Procter J, Ratter JA. (eds.) Nature and dynamics of the Forest-Savanna boundaries. London, Chapman \& Hall. p 21-33.

Janzen D. 1970. Herbivores and the number of tree species in tropical forests. American Naturalist 104: 501-528.

Jeltsch F, Weber G, Grimm V. 2000. Ecological buffering mechanisms in savannas: a unifying theory of long-term tree-grass coexistence. Plant Ecology 161: 161-171.

Kennedy A, Potgieter A. 2003. Fire season affects size and architecture of Colophospermum mopane in southern African savannas. Plant Ecology 167: 179-192.

Legendre P, Fortin M. 1989. Spatial pattern and ecological analysis. Vegetatio 80: 107-138.

Liebhold A, Gurevitch J. 2002. Integrating the statistical analysis of spatial data in ecology. Ecography 25: 553-557.

Miranda-Melo A, Martins FR, Santos FA. 2007. Estrutura populacional de Xylopia aromatica (Lam.) Mart. e de Roupala montana Aubl. em fragmentos de cerrado no Estado de São Paulo. Revista Brasileira de Botânica 30: 501-507.
Miranda-Melo A. 2004. Estrutura espacial de Xylopia aromatica (Lam.) Mart. e Roupala montana Aubl. em quatro fragmentos de cerrado. MSc Thesis, Universidade Estadual de Campinas, Brazil.

Motta PEF, Curi N, Franzmeier DP. 2002. Relation of soils and geomorphic surfaces in the Brazilian Cerrado. In: Oliveira PS, Marquis RJ. (eds.) The Cerrados of Brazil - ecology and natural history of a Neotropical Savanna. New York, Columbia University Press. p 13-32.

Oliveira RS, Bezerra L, Davidson EA, et al. 2005. Deep root function in soil water dynamics in cerrado savannas of central Brazil. Functional Ecology 19: 574-581.

Oliveira-Filho AT, Shepherd GJ, Martins FR, Stubblebine WH. 1989 Environmental factors affecting physiognomic and floristic variation in an area of cerrado in central Brazil. Journal of Tropical Ecology 5: 413-431.

Paulilo MTS, Felippe GM. 1995. Respostas de plântulas de Qualea grandiflora Mart. uma espécie arbórea do cerrado, à adição de nutrientes minerais. Revista Brasileira de Botânica 18: 109-112.

Perry JN. 1998. Measures of spatial pattern for counts. Ecology 79: 10081017.

Perry JN, Dixon PM. 2002. A new method to measure spatial association for ecological count data. Ecoscience 9: 133-141.

Ratter J. 1992. Transitions between cerrado and forest vegetation in Brasil. In: Furley PA, Proctor J, Ratter JA. (eds.) Nature and dynamics of forest-savanna boundaries. London, Chapman \& Hall. p 51-76.

Ratter J, Bridgewater S, Ribeiro JF. 2003. Analysis of the floristic composition of the Brazilian cerrado vegetation III: comparison of the woody vegetation of 376 areas. Edinburgh Journal of Botany 60: 57-109.

Raventós J, Wiegand T, Luis M. 2010. Evidence for the spatial segregation hypothesis: a test with nine-year survivorship data in a Mediterranean shrubland. Ecology 91: 2110-2120.

Ribeiro JF, Walter BMT. 1998. Fitofisionomias do bioma Cerrado. In: Sano SM, Almeida SP. (eds.) Cerrado: ambiente e flora. Planaltina, EMBRAPA- CPAC. p 89-152.

Schupp E. 1995. Seed-seedling conflicts, habitat choice, and patterns of plant recruitment. American Journal of Botany 82: 399-409.

Schurr F, Bossdorf O, Milton S, Schumacher J. 2004. Spatial pattern formation in semi-arid shrubland: a priori predicted versus observed pattern characteristics. Plant Ecology 173: 271-282.

Silva LO, Costa DA, Espírito-Santo K, et al. 2002. Levantamento florístico e fitossociológico em duas áreas de cerrado sensu stricto no Parque Estadual da Serra de Caldas Novas, Goiás. Acta Botanica Brasilica 16: 43-53.

Staver A, Archibald S, Levin S. 2011. Tree cover in sub-Saharan Africa: rainfall and fire constrain forest and savanna as alternative stable states. Ecology 92: 1063-1072.

Stoll P, Prati D. 2001. Intraspecific aggregation alters competitive interactions in experimental plant communities. Ecology 82: 319-327.

Tsujino R, Yumoto T. 2007. Spatial distribution patterns of trees at different life stages in a warm temperate forest. Journal of Plant Research 120: 687-695.

Weiser VL, Godoy SAP. 2001. Florística em um hectare de cerrado stritu senso na ARIE - Cerrado Pé-de-Gigante, Santa Rita do Passa Quatro, SP. Acta Botanica Brasilica 15: 201-212. 